\title{
Synthesis and Characterization of Soy Protein Isolate/MMT Nanocomposite Film for the Control Release of the Drug Ofloxacin
}

\author{
Preetishree Nayak, Sanjib Kumar Sahoo, Anamika Behera, \\ Prativa Kumari Nanda, P. L. Nayak, B. C. Guru \\ P. L. Nayak Research Foundation, Neelachal Bhavan, Odisha, India \\ E-mail: plnayak@rediffmail.com
}

Received March 2, 2011; revised March 24, 2011; accepted April 7, 2011

\begin{abstract}
Nanocomposites were prepared by blending soy protein isolate with different percentage of MMT by melt extrusion technique. The nanocomposites were characterized by using, XRD, TEM, SEM and TGA methods. The XRD studies indicated the absence of diffraction peaks for the bio-nanocomposites. From the TEM studies it was ascertained that the degree of exfoliation increased with increase in MMT content. The morphology of the nanocomposites was ascertained from the SEM studies. The degradation pattern of the nanocomposites was evaluated from the TG analysis. The drug delivery system of the nanocmposites was investtigated by blending the nanocomposites with ofloxacin at different $\mathrm{pH}$ media. The various kinetic parameters were evaluated and the mechanism of drug delivery has been postulated based on the kinetic data.
\end{abstract}

Keywords: Nanocomposites, Soy Protein, MMT, Drug Delivery, Ofloxacin

\section{Introduction}

Carrier-mediated drug delivery has emerged as a powerful methodology for the treatment of various pathologies. The therapeutic index of traditional and novel drugs is enhanced via the increase of specificity due to targeting of drugs to a particular tissue, cell or intracellular compartment, the control over release kinetics, the protection of the active agent or a combination of the above [1]. Polymer composites were proposed as drug carriers over 30 years ago and have received growing attention since, mainly due to their stability, enhanced loading capabilities and control over physicochemical properties [2,3]. In addition to systemic administration, localized drug release may be achieved using macroscopic drug depots close to the target site. In recent years, biodegradable polymers have attracted attention of researchers to be used as carriers for drug delivery systems [4-6].

Drug delivery plays an important role in the development of pharmaceutical dosage forms for the healthcare industry because often the duration of the drug release needs to be extended over a period of time [7]. This can be achieved by the incorporation of drugs into polymeric materials to control drug release at a pre-defined and reproducible rate for a prolonged duration. The majority of the drug delivery systems are fabricated from nondegradable polymers such as silicone, polyurethane and ethylene vinyl acetate copolymers, which are inexpensive, not biocompatible, and biologically inert and have received regulatory approval [8]. In recent years, the interest for biodegradable polymers as drug delivery systems, which control and prolong the action of therapeutic agents, has attracted attention of researchers [9]. The reason being that delivery systems based on biodegradable polymers do not require removal from the patients at the end of the treatment period due to their degradation into physiologically occurring compounds that can be readily absorbed and further excreted from the body. This provides significant benefits such as reducetion of patient stress, no second surgery and reduction in cost in terms of time spent by the end-users [10-12].The most important biodegradable polymers which have been used for controlled drug delivery are chitosan, soy protein, gelatin, sodium alginate, PLA, PCL, polyanhydrides and polyorthoesters $[13,14]$.

Soy protein isolate (SPI) is an abundant, inexpensive and renewable natural material. It is composed of almost exclusively of two globular protein fractions differenti- 
ated by sedimentation coefficient: 7S (b-conglycinin) and 11S (glycinin) [15]. Both fractions have the ability to form films by a two-step process. During the preheating step, proteins are unfolded and polymerized into soluble aggregates, followed by a cooling step and subsequent surface dehydration, which results in the formation of a film network through disulfide cross-linking and hydrophobic bonds $[16,17]$. In general, protein films are effecttive lipid, oxygen, and aroma barriers at low to intermediate relative humidity (RH). The water exclusion properties of SPI films are relatively poor due to the hydrophilic nature of soy proteins and to substantial amounts of added hygroscopic plasticizers $[18,19]$. Numerous studies have concentrated on improving the mechanical and water-excluding properties of soy protein-based films through physical, chemical and enzymatic treatments or compositing with hydrophobic materials in order to develop alternative resources for bio-plastics in packaging applications [20,21]. However, no investigation of SPI film as a controlled delivery system has been reported

Recently, a new class of materials represented by bio-nanocomposites (biopolymer matrix including proteins reinforced with nanoparticles such as montmorillonite) has proven to be the promising option in improving mechanical and barrier properties of biopolymers [22-26]. The bio-nanocomposites consist of a biopolymer matrix reinforced with particles (nanoparticles) having at least one dimension in the nanometer range $(1-100 \mathrm{~nm})$ and exhibit much improved properties due to high aspect ratio and high surface area of nanoparticles [27-29]. The most common class of materials used as nanoparticles are layered clay minerals such as montmorillonite (MMT), hectorite, sapnotite, and laponite. These clay minerals have been proven to be very effective due to their unique structure and properties. These clay minerals belong to the general family of 2:1 192 layered silicates indicating that they have 2 tetrahedral sheets sandwiching a central octahedral sheet [30]. MMT has a very high elastic modulus (178 GPa) as compared to most bio- polymers. The high value of elastic modulus enables MMT to improve mechanical properties of biopolymers by carrying a significant portion of the applied stress [31] There are four possible arrangements of layered clays dispersed in a polymer matrix - phase separated or immiscible (microcomposite), intercalated, exfoliated, and disordered intercalated (partially exfoliated). In an immiscible arrangement, platelets of layered clays exist as tactoids (stack of platelets) and the polymer encapsulates these tactoids. Intercalation occurs when a monolayer of extended polymer chains penetrates into the galleries (gap between layers of clay) of the layered silicates. Intercalation results in finite expansion $(2-3 \mathrm{~nm})$ of the silicate layers. However, these silicate layers remain parallel to each other.

In the present research program, nanocomposites were prepared by blending soy protein isolate with different percentage of MMT by melt extrusion technique. The nanocomposites were characterized by using SEM, TEM and XRD methods. The drug delivery system of the nanocmposites were investigated by blending the nanocomposites with ofloxacin at different $\mathrm{pH}$ media. The various kinetic parameters were evaluated and the mechanism of drug delivery has been postulated based on the kinetic data.

\section{Materials and Methods}

\subsection{Materials}

Soy protein isolate (Supro 760) with a protein content of 92.5\% (dry basis) was obtained from Protein Technologies International (St. Louis, MO). Two types of modified montmorillonites (Cloisite 20A and Cloisite 30B) were obtained from Southern Clay Products (Austin, TX).

\subsection{Preparation of SPI-MMT Nanocomposites}

The formulation consisted of SPI (70\% - 85\%, dry basis), glycerol (15\%, dry basis), and MMT (0\% - 15\%, dry basis). All three types of clays (Cloisite $\mathrm{Na}+$, Cloisite 20A, and Cloisite 30B) were used at four different levels $(0,5,10$, and $15 \%)$. The ingredients were mixed and left at room temperature for 2 hours for hydration. The mixture was subsequently extruded in a twinscrew co-rotating extruder (ZSK 26, Coperion Corp., Ramsey, NJ). The extruder had screw diameter of $25 \mathrm{~mm}$ and length to diameter ratio (L/D) of 20. The extruder was operated at a screw speed of $100 \mathrm{rpm}$. The extruder had a 5 head barrel configuration. Temperatures in the 5 head barrel were maintained at $60^{\circ} \mathrm{C}, 90^{\circ} \mathrm{C}, 100^{\circ} \mathrm{C}, 110^{\circ} \mathrm{C}$, and $90^{\circ} \mathrm{C}$ respectively. The extrudate was dried in an oven at $50^{\circ} \mathrm{C}$ for 48 hrs and grounded for use.

\subsection{Film Casting}

Bio-nanocomposite powders (4\% w/v) and deionized water were mixed for 30 min at room temperature. $\mathrm{pH}$ of the suspension was adjusted to 9 by adding $1 \mathrm{M} \mathrm{NaOH}$. The suspension was heated to $95^{\circ} \mathrm{C}$ and held at that temperature for $20 \mathrm{~min}$ with continuous stirring. Subsequently, the solution was cooled to $65^{\circ} \mathrm{C}$ and $25 \mathrm{ml}$ of the suspension was poured in $10 \mathrm{~cm}$ diameter petri dishes for casting nanocomposite films. The cast petri dishes were dried at ambient conditions for 48 hours. The dried films 
were peeled off the petri dish and pre-conditioned before further testing.

\subsection{Structural Characterization of SPI-MMT Films}

\subsubsection{X-Ray Diffraction (XRD)}

$\mathrm{X}$-ray diffraction studies of nanocomposite powders were performed with a diffraction unit (MS Philips XLF ATPS XRD 100, Omni Scientific Instruments, Biloxi, MS) operating at $35 \mathrm{kV}$ and $25 \mathrm{~mA}$. The radiation was generated from a $\mathrm{Cu}-\mathrm{K} \alpha$ source with a wavelength $(\lambda)$ of $0.154 \mathrm{~nm}$. The diffraction data was collected from $2 \theta$ values of 2.5 to $10^{\circ}$ with a step size of $0.01^{\circ}$, where $\theta$ is the angle of incidence of the $\mathrm{X}$-ray beam on the sample.

\subsubsection{Transmission Electron Microscopy (TEM)}

The structure and morphology of nanocomposite powders were visualized by a transmission electron microscope (Hitachi HF2000, Hitachi High-Technologies Europe $\mathrm{GmbH}$, Krefeld, Germany) operating at $200 \mathrm{kV}$. Samples of nanocomposite powders were prepared by suspending the powders in methanol. The suspension was sonicated for $5 \mathrm{~min}$ in an ultrasonic bath (Branson 1510, Branson Ultrasonics Co., Danbury, CT). A drop of the suspension was put on a fine-mesh carbon-coated TEM support grid (C-flatTM, Protochips Inc., Raleigh, NC). After drying in air, the nanocomposite powder remained attached to the grid and was viewed under the transmission electron microscope.

\subsubsection{Scanning Electron Microscopy (SEM)}

The morphology of the fracture surface (cross-sectional surface) of the nanocomposite films were visualized using a field emission scanning electron microscope (JEOL 6400F, Japan Electron Optics Ltd., Tokyo, Japan) operating at $5 \mathrm{kV}$. Small pieces $(0.5 \times 0.5 \mathrm{~cm})$ of bio nanocomposite films were frozen in liquid nitrogen, cut using a sharp razor blade, and mounted on specimen stubs with 2 sided carbon tape. The fracture surfaces of the films were sputter-coated with a thin layer $(\sim 8-10 \mathrm{~nm})$ of gold-palladium (Au-Pd) using a sputter-coater (Hummer II, Anatech Ltd., Union City, CA). After coating, the samples were viewed under the scanning electron microscope.

\subsection{Thermal Stability}

The thermal stability of nanocomposite films were investigated using a thermogravimetric analyzer (Pyris 1 TGA, Perkin Elmer, Shelton, CT). The temperature of the sample was increased from room temperature to $900^{\circ} \mathrm{C}$ at a heating rate of $20^{\circ} \mathrm{C} / \mathrm{min}$. Weight loss of the sample was measured as a function of temperature. Three parameters were determined from the TGA data: the temperature at $10 \%$ weight loss, the temperature at $50 \%$ weight loss, and the yield of charred residue at $850^{\circ} \mathrm{C}$.

\subsection{Drug Loading}

Required amount of SPI/MMT was taken in $5 \mathrm{ml}$ of acetic acid. The mixture was continuously stirred with a mechanical stirrer. Ofloxacin of different loadings, i.e., $10,20,30,40$ and $50 \mathrm{wt} \%$ were then added to the above mixture and stirred for $1 \mathrm{~h}$ and then the composites were kept at room temperature for drying.

\section{Results and Discussion}

\subsection{XRD}

XRD patterns (Cloisite 20A and Cloisite 30 B (0\%, 5\%, $10 \%$, and $15 \%$ ) of bionanocomposite powders are shown in Figure 1. Powders of Cloisite 20A showed a diffracttion peak at a $2 \theta$ angle of $3.56^{\circ}$. Interlayer distance ( $\mathrm{d}$ or d-spacing) between clay layers can be estimated from Bragg's equation as shown below.

$$
d=\frac{\lambda}{2 \sin \left(\frac{\pi \theta}{180}\right)}
$$

where $\lambda$ is the wavelength of $\mathrm{X}$-ray beam. The $\mathrm{d}$-spacing of Cloisite 20A corresponding to the diffraction peak was calculated to be $2.48 \mathrm{~nm}$. This is in close agreement with the d-spacing value of $2.42 \mathrm{~nm}$ provided by the supplier. XRD patterns of Cloisite 30B and SPI-Cloisite 30B ( $0 \%, 5 \%, 10 \%$, and $15 \%)$ nanocomposite powders are shown in Figure 2. The d-spacing of Cloisite 30B corresponding to the diffraction peak at a $2 \theta$ angle of $5.0^{\circ}$ was calculated to be $1.77 \mathrm{~nm}$. There was no diffraction peak in the $2 \theta$ range of $2.5^{\circ}$ to $10^{\circ}$ for the nanocomposites at all MMT contents of Cloisite 20A and Cloisite 30B. Absence of diffraction peaks for SPI-MMT bio-nanocomposites suggests that the layers of MMTs have a d-spacing of at least $3.53 \mathrm{~nm}$ (corresponding to a $2 \theta$ value of $2.5^{\circ}$ ) in all the bio-nanocomposites.

\subsection{TEM}

TEM images of SPI-MMT nanocomposite powders with $5 \%$ and $15 \%$ contents of Cloisite 20A and Cloisite 30B are shown in Figure 3. The dark lines in the TEM images correspond to MMT platelets and the gap between two adjacent lines is the d-spacing. It can be seen from Figures 3(a) and 3(c) that the MMT layers are exfoliated in nanocomposites with MMT content of 5\%. At MMT 


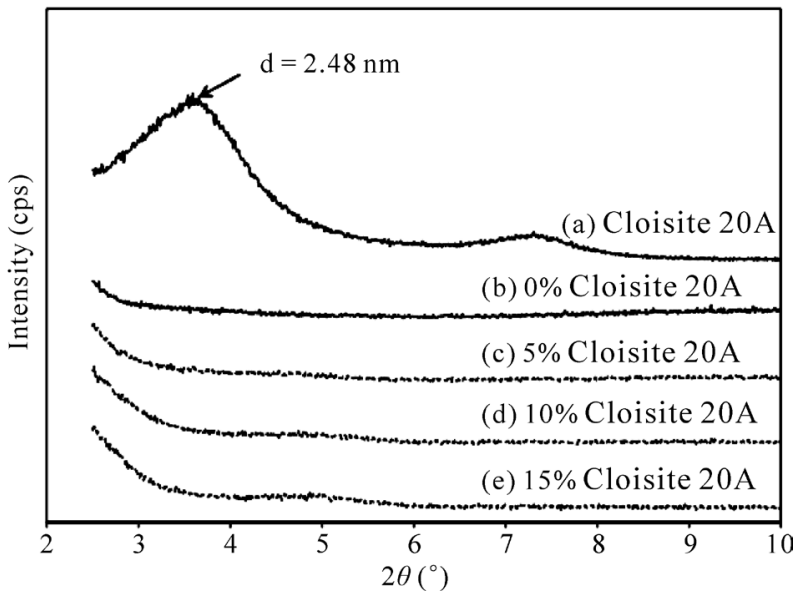

Figure 1. XRD patterns of Cloisite 20A and SPI-Cloisite 20A bio-nanocomposites with different Cloisite 20A contents.

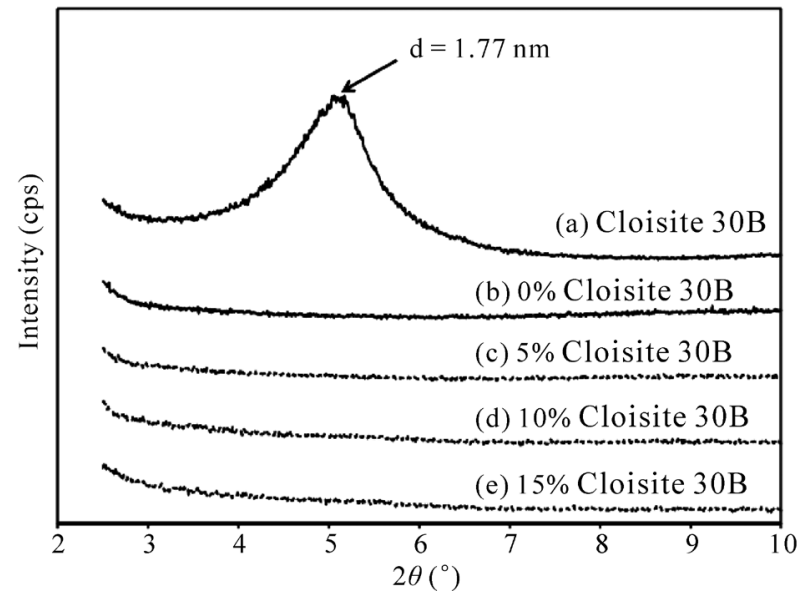

Figure 2. XRD patterns of Cloisite 30B and SPI-Cloisite 30B bio-nanocomposites with different Cloisite 30B contents.

content of 15\%, MMT layers are intercalated in nanocomposites with Cloisite 20A (Figure 3(b)) whereas the arrangement of MMT changed from exfoliated to disordered intercalated (Figure 3(d)) for nanocomposites with Cloisite 30B. However, d-spacing values, which ranged from 4 to $10 \mathrm{~nm}$, were higher than the detection limit of XRD analysis $(3.53 \mathrm{~nm})$. This explains the absence of diffraction peaks for these bio-nanocomposites in the XRD analysis. It can also be concluded that XRD by itself is insufficient to characterize the structure of nanocomposites for intercalated and disordered intercalated arrangements.

\subsection{SEM}

SEM images of the fracture surface (cross-sectional surface) of SPI-MMT nanocomposite films with 5\% and $15 \%$ contents of Cloisite 20A and Cloisite 30B are shown in Figure 4. The white strands in the SEM images

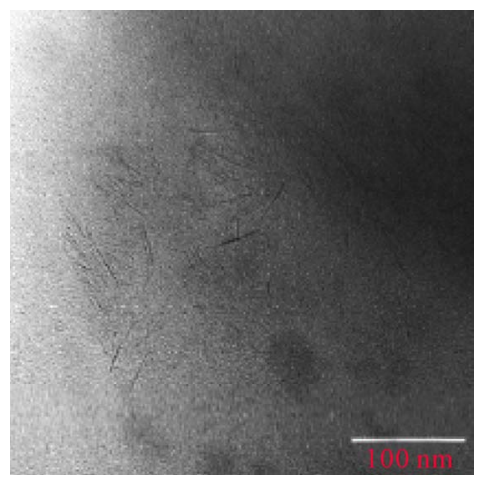

(a)

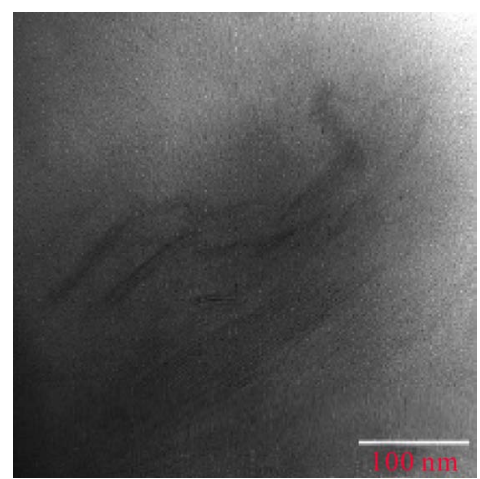

(b)

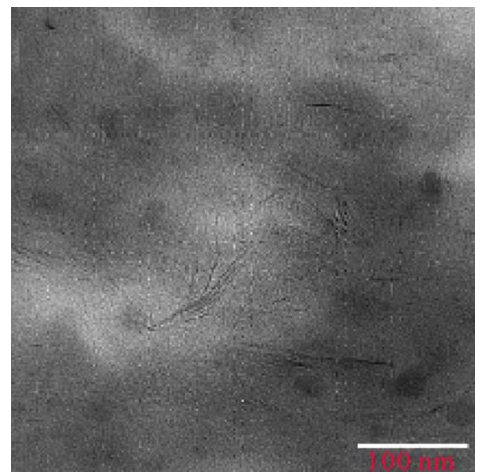

(c)

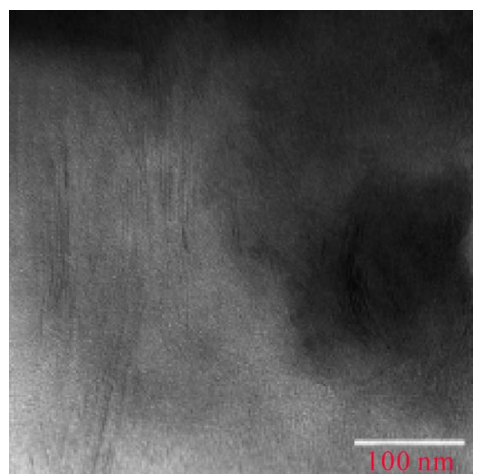

(d)

Figure 3. TEM images of bio-nanocomposites with (a) $\mathbf{5 \%}$ Cloisite 20A; (b) 15\% Cloisite 20A; (c) 5\% Cloisite 30B; and (d) 15\% Cloisite 30B. 
correspond to MMT platelets. At a MMT content of 5\%, MMT platelets were well dispersed in the nanocomposite films (Figures 4(a) and 4(c)). This suggests exfoliation of MMT in the nanocomposite film with MMT content of $5 \%$. The fracture surface of the films with both Cloisite 20A and Cloisite 30B became rougher as the MMT content increased to 15\% (Figures 4(b) and 4(d)). In agreement with the TEM results of intercalated structures, larger aggregates of Cloisite 20A were found in nanocomposite films with MMT content of 15\% (Figure 4(d)). Based on the XRD, TEM, and SEM results, it can be concluded that extrusion of SPI and modified MMTs resulted in nanocomposites with exfoliated structures at lower MMT content (5\%). At higher MMT content (15\%), the structure of nanocomposites ranged from intercalated for Cloisite 20A to disordered intercalated for Cloisite 30B.

\subsection{TGA}

TGA curves of nanocomposite films based on SPI and modified MMTs at MMT contents of $0 \%, 5 \%$, and $15 \%$ are shown in Figure 5. It can be seen from Figure 5 that there are 3 steps of thermal degradation of the films in the temperature range of $100^{\circ} \mathrm{C}$ to $900^{\circ} \mathrm{C}$. The thermal deg- radation between $100^{\circ} \mathrm{C}$ to $150^{\circ} \mathrm{C}$ corresponds to the loss of water absorbed in the films. The temperature range for the second step of thermal degradation is $300^{\circ} \mathrm{C}$ to $400^{\circ} \mathrm{C}$. This corresponds to the decomposition of soy protein, decomposition of organic modifiers of modified MMT, and loss of glycerol from the films. The third step of thermal degradation is in the temperature range of $500^{\circ} \mathrm{C}$ to $750^{\circ} \mathrm{C}$. This might be due to oxidation of partially de- composed soy protein and organic modifiers under air flow.

The temperature at 50\% weight loss (during TGA) for SPI films was $355.5 \pm 2.2^{\circ} \mathrm{C}$. The temperatures at $50 \%$ weight loss for nanocomposite films with $5 \%$ of Cloisite $20 \mathrm{~A}$ and Cloisite $30 \mathrm{~B}$ were $367.7 \pm 1.7^{\circ} \mathrm{C}$ and $378.6 \pm$ $2.3^{\circ} \mathrm{C}$ respectively. These temperatures are comparable to the temperature at $50 \%$ weight loss of $377.3 \pm 2.6^{\circ} \mathrm{C}$ for nanocomposite

films based on SPI and 5\% natural MMT (Cloisite $\mathrm{Na}+$ ). As the MMT content increased, the nanocomposite films exhibited a significant delay in weight loss at temperatures greater than $500^{\circ} \mathrm{C}$. The yield of charred residue at $850^{\circ} \mathrm{C}$ for SPI films was $4.2 \pm 0.3 \%$. The yields of charred residue at $850^{\circ} \mathrm{C}$ for nanocomposite films with $15 \%$ of Cloisite 20A and Cloisite 30B were $10.9 \pm 0.6 \%$ and $11.2 \pm 0.4 \%$ respectively. These yields of charred residue for modified MMTs are much lower than that $(20.5 \pm 0.4 \%)$ of nanocomposite films based on SPI and $15 \%$ natural MMT (Cloisite $\mathrm{Na}+$ ). This reduction in

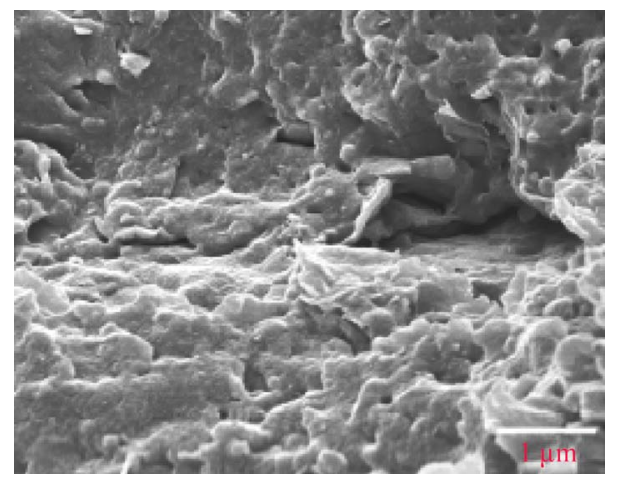

(a)

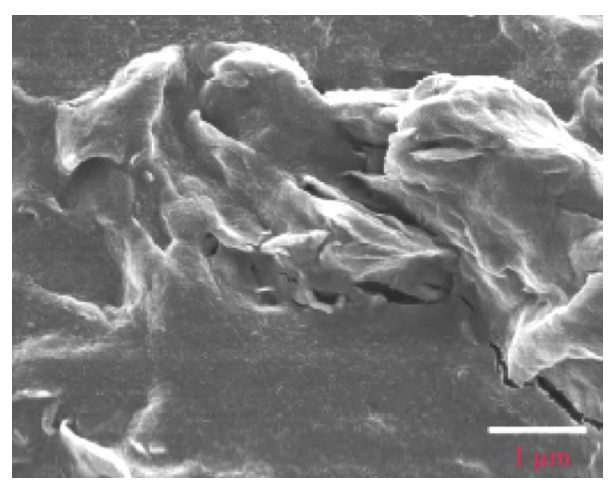

(b)

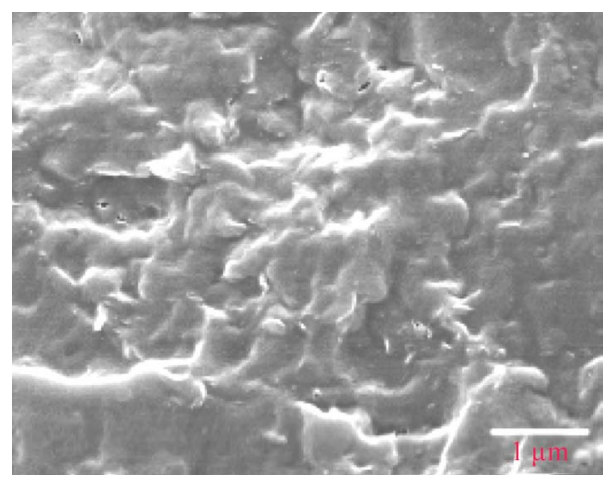

(c)

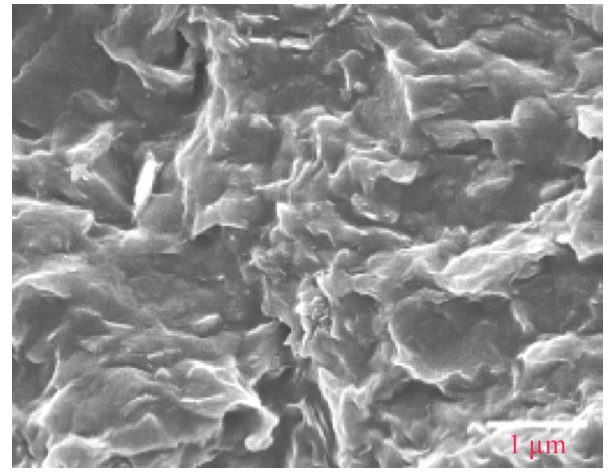

(d)

Figure 4. SEM images of bio-nanocomposite films with (a) 5\% Cloisite 20A; (b) 15\% Cloisite 20A; (c) 5\% Cloisite 30B; and (d) $15 \%$ Cloisite 30B. 


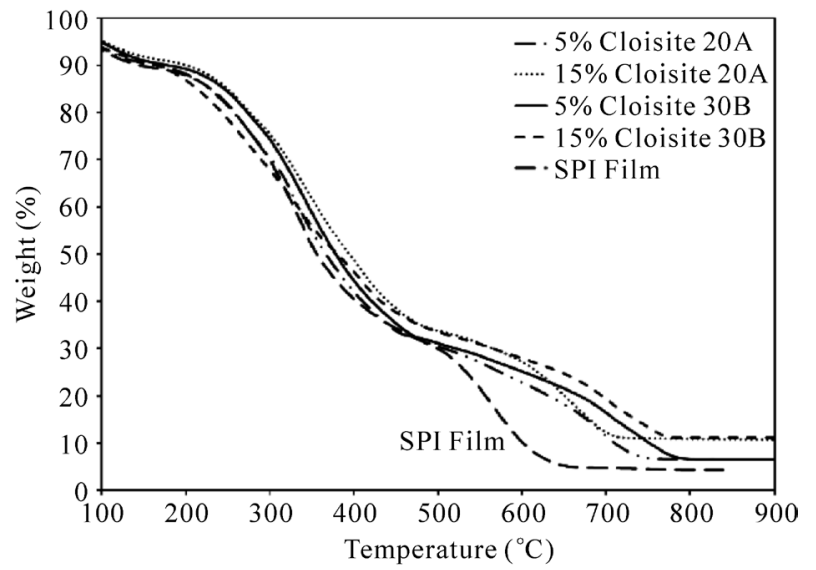

Figure 5. TGA curves of bio-nanocomposite films based on SPI and modified MMTs at different MMT contents under air flow.

yields of charred residue is attributed to the thermal decomposition of organic modifier of modified MMTs. Cloisite 20A and Cloisite 30B contain 36.4\% and 52.4\% of organic modifiers respectively.

\subsection{Dissolution Experiments}

Dissolution experiments were performed at $37^{\circ} \mathrm{C}$ using the dissolution tester equipped with six paddles at a paddle speed of $100 \mathrm{rpm}$. About $900 \mathrm{ml}$ of phosphate buffer solution ( $\mathrm{pH} 7.4$ and 3.4) was used as the dissolution media to stimulate gastrointestinal tract (GIT) conditions. A 5-ml aliquot was used each time for analyzing the ofloxacin content at a fixed time interval. The dissolution media was replenished with a fresh stock solution. The amount of ofloxacin released was analyzed using a UV spectrophotometer at the $\lambda$ max value of $287 \mathrm{~nm}$.

The drug delivery system was developed for the purpose of bringing-up, taking, retaining, releasing, activateing, localizing and targeting the drugs at the right time period, dose and place. The biodegradable polymer can contribute largely to this technology by adding its own characters to the drugs. In this connection, some biodegradable polymers, such as PLA, PCL, are commonly used as these can be prepared in the moderate conditions, has a similar stiffness of the body and has an appropriate biodegradability and low crystallinity enough to be mixed well with many kinds of drug. There are some formulations for the drug delivery systems, such as, films, gels, porous matrices, microcapsules, micro spheres, nanoparticles, polymeric micelles and polymer-linked drugs.

\subsection{Effect of $\mathbf{p H}$}

In order to investigate the effect of $\mathrm{pH}$ on the drug deliv- ery of composite SPI/MMT, we have measured the \% cumulative release in both $\mathrm{pH} 3.4$ and 7.4 media. Cumulative release data presented in Figure 6 indicate that by increasing the $\mathrm{pH}$ from 3.4 to 7.4 , a considerable increase in the cumulative release is observed for all composites. From Figure 6(a) and 6(b), it is seen that the $50 \%$ drug-polymer composites have shown longer drug release rates than the other composites. Thus, drug release depends upon the nature of the polymer matrix as well as $\mathrm{pH}$ of the media. This suggests that the drugs in the blend can be used to be suitable for the basic environment of the large intestine, colon and rectal mucosa for which there are different emptying times. Interestingly, ofloxacin is being released more rapidly at $\mathrm{pH} 7.4$ than at $\mathrm{pH} 3.4$, the release half times $t_{50}$ (time required for releasing $50 \mathrm{wt} \%$ of drug) for $10 \%, 20 \%, 30 \%, 40 \%$, $50 \%$ drug loading are 2.8, 1.8 and $1.7 \mathrm{~h}$ at $\mathrm{pH} 7.4$, and 6.0, 5.0 and $4.4 \mathrm{~h}$ at $\mathrm{pH} 3.4$, respectively are shown in Figure 7. More than $80 \mathrm{wt} \%$ ofloxacin is released from composites at $\mathrm{pH} 7.4$ within $8 \mathrm{~h}$, whereas less than 44 wt\% of the drug is released at $\mathrm{pH} 3.2$ within $4 \mathrm{~h}$. This suggests that the drugs in the composites can be used to

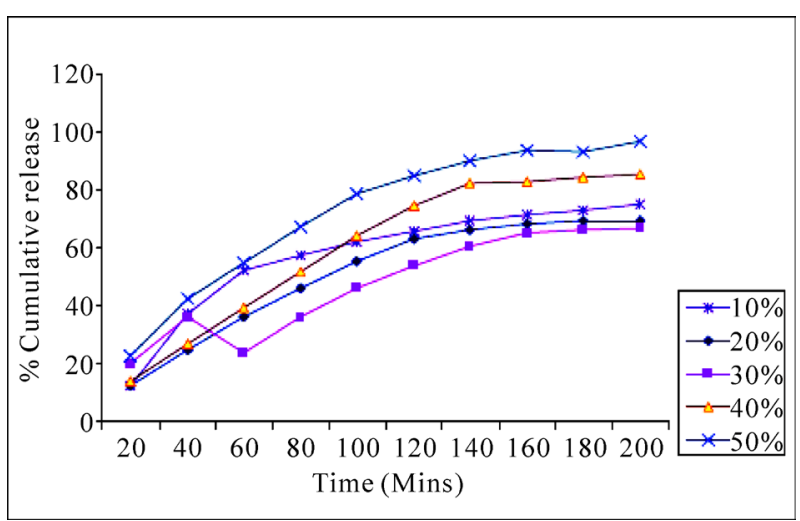

(a)

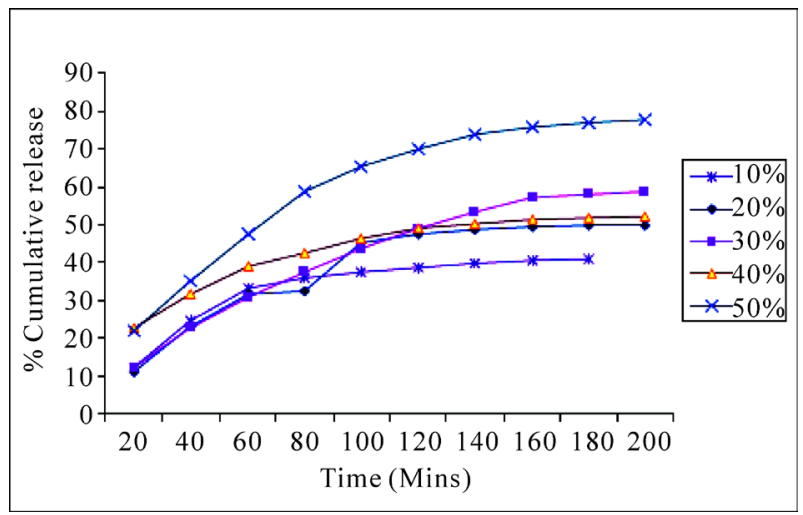

(b)

Figure 6. \% Cumulative release Vs Time for different formulation loaded with SPI: (a) $5 \%$ Cloisite $30 \mathrm{~B}$ in $7.4 \mathrm{pH}$ media; (b) $5 \%$ Cloisite $30 \mathrm{~B}$ in $3.4 \mathrm{pH}$ media. 

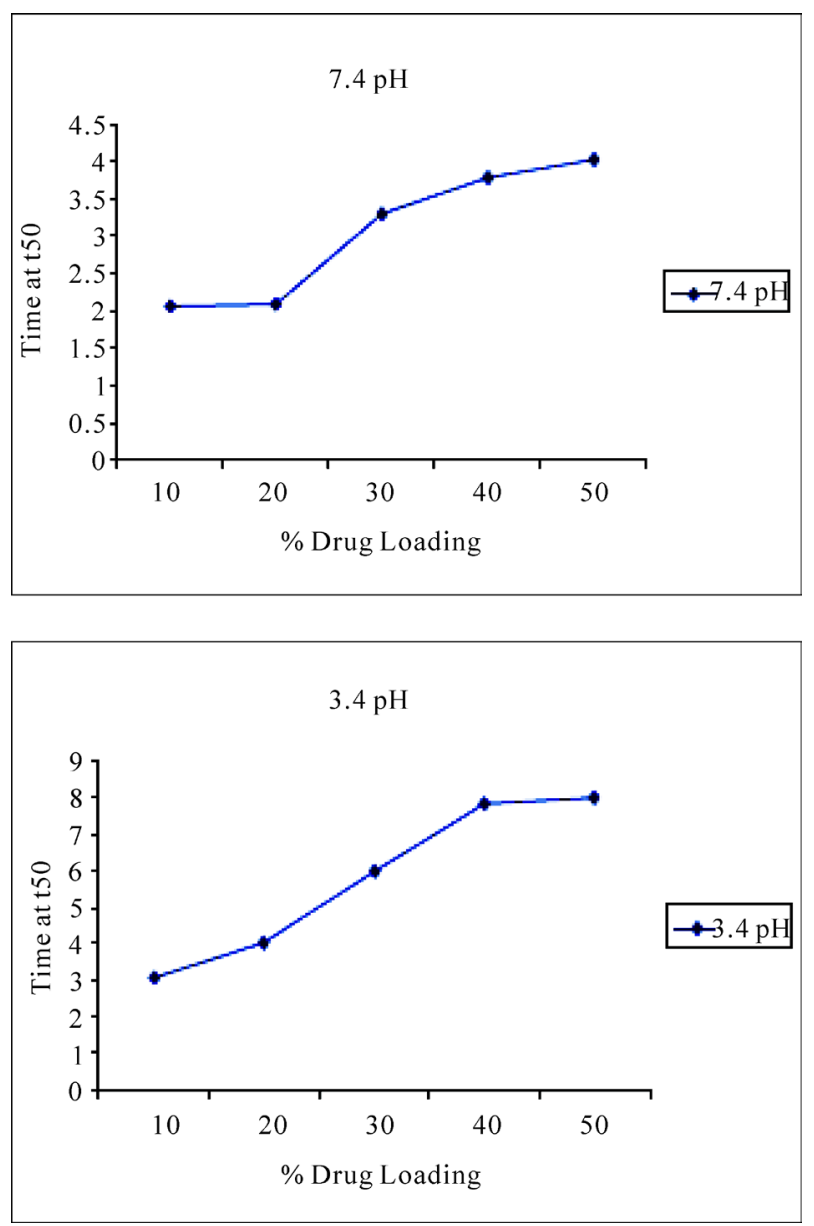

Figure 7. \% Cumulative release Vs. Time for different formulation loaded with SPI: $5 \%$ Cloisite 30 Bin (A) pH 7.4 and pH 3.4 media.

be suitable for the basic environment. Further the electrostatic interaction of composites is more easily broken at $\mathrm{pH} 7.4$ than at $\mathrm{pH} 3.4$, leading to ofloxacin being released more rapidly at $\mathrm{pH} 7.4$ than 3.4.

\subsection{Effect of Drug Loading}

Figure 7 displays the release profiles of drug from composites at different amounts of drug loadings. Release data show that formulations containing highest amount of drug (50\%) displayed fast and higher release rates than those formulations containing a small amount of drug loading. The release rate becomes quite slower at the lower amount of drug in the matrix, due to the availability of more free void spaces through which a lesser number of drug molecules could transport.

\subsection{Drug Release Kinetics}

From time to time, various authors have proposed several types of drug release mechanisms from matrices. It has been proposed that drug release from matrices usually implies water penetration in the matrix, hydration, swelling, diffusion of the dissolved drug (polymer hydro fusion), and/or the erosion of the gelatinous layer. Several kinetics models relating to the drug release from matrices, selected from the most important mathematical models, are described over here. However, it is worth mention that the release mechanism of a drug would depend on the dosage from selected, $\mathrm{pH}$, nature of the drug and, of course, the polymer used. The following kinetic equations are being used to study the drug releas kinetics.

1) Zero-order kinetics [32]

$$
W=k_{1} t
$$

2) First-order kinetics [33]

$$
\operatorname{In}(100-W)=\operatorname{In} 100-k_{2} t
$$

3) Hixon-Crowel's cube-root equation [34]

$$
(100-W)^{1 / 3}=100^{1 / 3}-k_{3} t
$$

4) Higuchi's square root of time equation [35]

$$
W=k_{4} t
$$

5) Power law equation (diffusion/relaxation model) [36]

$$
M_{t} / M_{\infty}=k_{s} t^{n}
$$

is the fractional drug release into dissolution medium and $k_{5}$ is a constant incorporating the structural and geometric characteristics of the tablet. The term ' $n$ ' is the diffusional constant that characterizes the drug release transport mechanism. When $n=0.5$, the drug diffuses through and is release from the polymeric matrix with a quasi-Fickian diffusion mechanism. For $n>0.5$, an anomalous, non-Fickian drug diffusion occurs. When $n=1$, a non-Fickian, case II or zero-order release kinetics could be observed. Drug release kinetics was analyzed by plotting the cumulative release data vs. time by fitting to an exponential equation of the type as represented below.

$$
M_{t} / M_{\infty}=k t^{n}
$$

Here, Mt/M represents the fractional drug release at time $t, k$ is a constant characteristic of the drug-polymer system and $\mathrm{n}$ is an empirical parameter characterizing the release mechanism. Using the least squares procedure, we have estimated the values of $n$ and $k$ for all the nine formulations and these data are given in Table 1. The values of $\mathrm{k}$ and $\mathrm{n}$ have shown a dependence on the, \% drug loading and polymer content of the matrix. Values of $\mathrm{n}$ for composites prepared by varying the amounts of drug containing 10, 20 and 30, 40, and 50 wt\% and, ranged from 0.57 to 1.13 suggesting shift of drug transport from Fickian to anomalous type. The values of $n$ 
Table 1. Kinetic parameters of different formulations at $\mathbf{p H}$ 7.4 and $\mathrm{pH} 3.4$.

\begin{tabular}{cccc}
\hline $\begin{array}{c}\text { Sample } \\
\text { Code(\%) }\end{array}$ & $\mathrm{k}$ & $\mathrm{n}$ & $\begin{array}{c}\text { co-ordination } \\
\text { coefficient, } \mathrm{R}\end{array}$ \\
\hline $7.4(\mathrm{pH})$ & & & \\
10 & 0.10 & 0.57 & 0.9872 \\
20 & 0.17 & 0.63 & 0.9843 \\
30 & 0.24 & 0.85 & 0.9675 \\
40 & 0.26 & 1.07 & 0.9863 \\
50 & 0.28 & 1.12 & 0.9765 \\
$3.4(\mathrm{pH})$ & & & \\
10 & 0.12 & 0.54 & 0.9785 \\
20 & 0.17 & 0.87 & 0.9872 \\
30 & 0.23 & 0.98 & 0.9832 \\
40 & 0.25 & 1.03 & 0.9876 \\
50 & 0.22 & 1.13 & 0.9865 \\
\hline
\end{tabular}

more than 1 has also been recently reported This may be due to a reduction in the regions of low micro viscosity inside the matrix and closure of microcavities during the swollen state of the polymer. Similar findings have been found elsewhere, wherein the effect of different polymer ratios on dissolution kinetics was investigated [37-39].

\section{Conclusions}

The last two decades of the twentieth century saw a paradigm shift from biostable biomaterials to biode-gradable (hydrolytically and enzymatically degradable) biomaterials for medical and related applications The current trend predicts that in the next couple of years in the twenty first century, many of the permanent prosthetic devices used for temporary therapeutic applications will be replaced by biodegradable devices that could help the body to repair and regenerate the damaged tissues. Soy protein isolate (SPI) is a natural biodegrade- able, biocompatible and nontoxic polymer. The blending of SPI with MMT has the advantage of enhancing some of the important properties of the base polymer. The nanocomposites have been characterized by using XRD, TEM, SEM and TGA methods to ascertain the exact characteristic properties of the composite materials. The control drug delivery application of the nanocompiosite has been investigated by blending it with ofloxacin and the drug delivery kinetics has been monitored by using the kinetic equations at two different $\mathrm{PH}$ media. The drug release is faster at $\mathrm{pH} 7.4$ than at $\mathrm{pH}$ 3.4. The various kinetic parameters have been computed and based on the values of the kinetic parameters such as $k$ and $n$ values the mechanism of drug diffusion from the nanocomposite matrix has been postulated. From the computed $k$ and $n$ values it is concluded that the drug release takes the anomalous path rather than Fickian path.

\section{References}

[1] S. N. Swain, K. K. Rao and P. L. Nayak, "Biodegradable Polymers: IV. Spectral, Thermal, and Mechanical Properties of Cross-Linked Soy Protein Concentrate,” Polymer international, 2005, Vol. 54, No. , 2005, pp. 739.

[2] P. K. Nanda, K. K. Rao and P. L. Nayak, "Spectral, Thermal, Morphological, 548 and Biodegradability Properties of Environment-Friendly Green Plastics of Soy Protein Modified with Thiosemicarbazide," Journal of Applied Polymer Science, Vol. 103, No. 5, March 2007, pp. 3134-3142. doi:10.1002/app.24590

[3] P. K. Nanda, K. K. Rao and P. L. Nayak, "Thermal Degradation Analysis of 550 Biodegradable plastics from Urea-Modified Soy Protein Isolate,” Polymer-Plastics Technology and Engineering, Vol. 46, No. , 2007, pp. 207. doi:10.1080/03602550601152713

[4] C. P. Pathak, A. S. Sawhney and J. A. R. Hubbell, "Photo Polymerization of Immuno Protective Gels in Contact with Cells and Tissue," Journal of American Chemical Society, Vol. 114, No. 21, October 1992, pp. 8311-8312. doi:10.1021/ja00047a065

[5] G. Lambert, E. Fatale and P. Couvreur, "Nanoparticulate Systems for the Delivery of Antisense Oligonucleotides," Advanced Drug Delivery Reviews, Vol. 47, No. 1, March 2001, pp. 99-112. doi:10.1016/S0169-409X(00)00116-2

[6] K. McAllister, P. Sanzani, M. Adam and M. J. Rubinstein, "Polymeric Nanogels Produced via Inverse Microemulsion Polymerization as Potential Gene and Antisense Delivery Agents,” Journal of American Chemical Society, Vol. 124, No. 51, 2002, pp. 15198-15207. doi:10.1021/ja027759q

[7] P. Legrand and G. Barratt, "Polymeric Nanocapsules as Drug Delivery System,” STP Pharma Sciences, Vol. 9, No. , 1991, pp. 411-418.

[8] J Jagur-Grodzinski, "Biomedical Application of Functional Polymers," Reactive and Functional Polymers, Vol. 39, No. 2, February 1999, pp. 99-138. doi:10.1016/S1381-5148(98)00054-6

[9] S Ramakrishna and J. Mayer, "Biomedical Application of Polymer Composite Materials,” Composites Science and Technology, Vol. 61, No. 9, July 2001, pp. 1189-1224. doi:10.1016/S0266-3538(00)00241-4

[10] D. Allen, Maysinger and A. Eisenberg, "Nano-Engineering Block Co-Polymers Aggregates for Drug Delivery," Colloids and Surfaces B: Biointerfaces, Vol. 16, No. 1-4, November 1999, pp. 3-27. doi:10.1016/S0927-7765(99)00058-2

[11] H. Maeda, T Sawa and T. Konno, "Mechanism of Tumor Targeted Delivery Macromolecular Drugs including the EPR Effect in Solid Tumor and Clinical Overview of the 
Prototyoe Polymeric Drugs," Journal of Controlled Release, Vol. 74, No. 1-3, July 2001, pp. 47-61. doi:10.1016/S0168-3659(01)00309-1

[12] V. B. Pokharkar and S. Sivaram, "Permeabilty Studies across Poly (alkylene carbonate) Membranes,” Journal of Controlled Release, Vol. 41, No. 3, September 1996, pp. 157-162. doi:10.1016/0168-3659(96)01325-9

[13] C. J. Goodwin, M. Braden, S. Downes and N. J. Marshall, "Release of Bioactive Human Growth Hormone from a Biodegradable Material Poly(epsilon-caprolactone)," Journal of Biomedical Materials Research, Vol. 40, No. 2, May 1998, pp. 204-13. doi:10.1002/(SICI)1097-4636(199805)40:2<204::AID-JB M5>3.0.CO;2-P

[14] C. G. Pitt, M. M. Gratzl, A. R. Jeffcoat, R. Zweidinger and A. Schindler, "Sustained Drug Delivery System II: Factors Affecting Release Rate from Poly(e caprolactone), and Related Biodegradable Polyesters," Journal of Pharmaceutical Sciences, Vol. 68, No. 12, December 1979, pp. 1534-1538. doi:10.1002/jps.2600681219

[15] E. Tomlinson and J. J. Burger, "Incorporation of Water Soluble Drugs in Albumin Microspheres,” In: J. Widder and R. Green, Eds., Methods in Enzymology, Academic Press, New York, 1985, pp. 27-43.

[16] A. Gennadios and C. L. Weller, "Edible Films and Coatings from Soymilk and Soy Protein," Cereal Foods World, Vol. 36, No. , 1991, pp. 1004-1009.

[17] M. Subirade, I. Kelly, J. Gueguen and M. Pezolet, "Molecular Basis of Film Formation from a Soybean Protein: Comparison between the Conformation of Glycinin in Aqueous Solution and in Films," International Journal of Biological Macromolecules, Vol. 23, No. 4, November 1998, pp. 241-249. doi:10.1016/S0141-8130(98)00052-X

[18] A. Gennadios, T. H. McHugh, C. L. Weller and J. M. Krochta, "Edible Coatings and Films Based on Proteins," In: J. M. Krochta, E. A. Baldwin and M. Nisperos-Carriedo, Eds., Edible Coatings and Films to Improve Food Quality, Technomic Publishing Company, Lancaster, 1994. pp. 201-277.

[19] J. M. Krochta and C. D. De Mulder-Johnston, "Edible and Biodegradable Polymer Films: Challenges and Opportunities,” Food Technology, Vol. 51, No. , 1997, pp. 61-74.

[20] A. H. Brandenburg, C. L. Weller, R. F. Testin, "Edible Films and Coatings from Soy Protein," Journal of Food Science, Vol. 58, No. 5, September 1993, pp. 1086-1089. doi:10.1111/j.1365-2621.1993.tb06120.x

[21] A. Gennadios, V. M. Ghorpade, C. L. Weller and M. A. Hanna, "Increase in Water Vapor Barrier Properties of Biopolymer-Based Edible Films and Coatings by Compositing Lipid Materials,” Food Science and Biotechnology, Vol. 13, No. , 1996, pp. 528-535.

[22] J. W. Rhim, A. Gennadios, C. L. Weller, C. Cezeirat and M. A. Hanna, "Soy Protein Isolatedialdehyde Starch Films,” Industrial Crops and Products, Vol. 8, No. 3, September 1998, pp. 195-203. doi:10.1016/S0926-6690(98)00003-X

[23] P. L. Nayak and J. Macromol, "Biodegradable Polymer:
Opportunities and Challenges,” Sci.Rev.Macromol. Chem. Phys., Vol. 39, No. , 1999, pp. 481-505.

[24] P. L. Nayak and J. Macromol, "Natural Oil Based Polymers: Opportunities and Challenges,” Sci.Rev.Macromol. Chem. Phys., Vol. 40, No. 1, 2000, pp. 1-21.

[25] S. N. Swain, S. M. Biswal, P. K. Nanda and P. L. Nayak, "Biodegradable Soy-Based Plastics: Opportunities and Challenges," Journal of Polymers and the Environment, Vol. 12, No. 1, 2004, pp. 35-42. doi:10.1023/B:JOOE.0000003126.14448.04

[26] S. N. Swain, K. K. Rao and P. L. Nayak, "Biodegradable Polymers. III. Spectral, Thermal, Mechanical, and Morphological Properties of Cross-Linked Furfural-Soy Protein Concentrate," Journal of Thermal Analysis and Calorimetry, Vol. 93, No. , 2004, pp. 2590.

[27] S. S. Ray and M. Bousmina, "Biodegradable Polymers and Their Layered Silicate Nanocomposites: In Greening the 21st Century Materials World,” Progress in Materials Science, Vol. 50, No. 8, November 2005, pp. 962-1079. doi:10.1016/j.pmatsci.2005.05.002

[28] J. W. Rhim and P. K. W. Ng, "Natural Biopolymer-Based Nanocomposite Films for Packaging Applications," Critical Reviews in Food Science and Nutrition, Vol. 47, No. 4, 2007, pp. 411-433. doi:10.1080/10408390600846366

[29] R. Zhao, P. Torley and P. J. Halley, "Emerging Biodegradable Materials: Starch- and Proteinbased Bio-Nanocomposites,” Journal of Materials Science, Vol. 43, No. , 2008, pp. 3058-3071. doi:10.1007/s10853-007-2434-8

[30] T. D. Fornes and D. R. Paul, 2003. "Modeling Properties of Nylon 6/Clay Nanocomposites Using Composite Theories,” Polymer, Vol. 44, No. 17, August 2003, pp. 4993-5013. doi:10.1016/S0032-3861(03)00471-3

[31] H. R. Dennis, D. L. Hunter, D. Chang, S. Kim, J. L. White, J. W. Cho and D. R. Paul, "Effect of Melt Processing Conditions on the Extent of Exfoliation in Organoclay-Based Nanocomposites,” Polymer, Vol. 42, No. 23, November 2001, pp. 9513-9522. doi:10.1016/S0032-3861(01)00473-6

[32] J. W. Rhim, Y. Wu, C. L. Weller and M. Schnepf, "Physical Characteristics of a Composite Films of Soy Protein Isolate and Propyleneglycol Alginate,” Journal of Food Science, Vol. 64, No. 1, 1999, pp. 149-152. doi:10.1111/j.1365-2621.1999.tb09880.x

[33] K. Dean and L. Yu, "Biodegradable Protein-Nanoparticles Composites,” In: R. Smith, Ed., Biodegradable Polymers for Industrial Applications, Woodhead Publishing Ltd., UK, 2005, pp. 289-312. doi:10.1533/9781845690762.2.289

[34] A. K. Singla and D. K. Medirata, "Influence of sodium Lauryl Sulfate on Indomethacin Release Patterns,” Drug Development and Industrial Pharmacy, Vol. 14, No. , 1988, pp. 1883-1888. doi:10.3109/03639048809151994

[35] T. Higuchi, "Mechanism of Rate of Sustained-Action Medication,” Journal of Pharmaceutical Sciences, Vol. 52, No. 12, December 1963, pp. 1145-1149. doi:10.1002/jps.2600521210

[36] A. R. Kulkarni, K. S. Soppimath and T. M. Aminabhavi, 
"Controlled Release of Diclofenac Sodium from Sodium Alginate Beads Crosslinked with Glutaraldehyde,” Phramaceutica Acta Helvitae, Vol. 74, No. 1, December 1999, pp. 29-36. doi:10.1016/S0031-6865(99)00015-1

[37] T. M. Aminabhavi and H. G. Naik, "Chemical Compatibility Study of Geomembranes-Sorption/Desorption, Diffusion and Swelling Phenomena," Journal of $\mathrm{Ha}$ zardous Materials, Vol. 60, No. 2, June 1998, pp. 175203. doi:10.1016/S0304-3894(98)00090-9
[38] S. P. Lyu, R. Sparer, C. Hobot and K. Dang, “Adjusting Drug Diffusivity Using Miscible Polymer Blends,” Journal of Controlled Release, Vol. 102, No. 3, February 2005, pp. 679-687. doi:10.1016/j.jconrel.2004.11.007

[39] R. L Ritger and N. A. Peppas, "A Simple Equation for Disposition of Solute Release-II," Journal of Controlled Release, Vol. 5, No. 1, June 1987, pp. 37-42. doi:10.1016/0168-3659(87)90035-6 